\title{
Joystick Device
}

National Cancer Institute

\section{Source}

National Cancer Institute. Joystick Device. NCI Thesaurus. Code C50015.

A control device that uses a movable handle to create two-axis input for a computer device. 